\title{
PENGARUH LAMA WAKTU FERMENTASI LIMBAH BUAH NANAS (Ananas comosus $L$. Merr) TERHADAP KUALITAS FISIK DAN KANDUNGAN NUTRIEN MENGGUNAKAN Aspergillus niger
}

\author{
The Effect Lenght of Fermentation of Pineapple Fruit Waste (Ananas comosus \\ L. Merr) on the Physical Quality and Nutrient Content Using Aspergillus niger \\ Adi Prasetya Kusuma ${ }^{1)}$, Siti Chuzaemi ${ }^{2)}$, dan Mashudi ${ }^{2)}$ \\ 1) Mahasiswa Bagian Nutrisi dan Makanan Ternak, Fakultas Peternakan, Universitas Brawijaya Jalan Veteran, \\ Ketawanggede, Kec. Lowokwaru, Kota Malang, Jawa Timur 65145 \\ ${ }^{2)}$ Dosen Bagian Nutrisi dan Makanan Ternak, Fakultas Peternakan, Universitas Brawijaya Jalan Veteran, \\ Ketawanggede, Kec. Lowokwaru, Kota Malang, Jawa Timur 65145 \\ Email : adiprasetyakusuma17@gmail.com
}

\begin{abstract}
ABSTRAK
Tujuan penelitian ini adalah untuk mengetahui pengaruh lama waktu fermentasi limbah buah nanas dengan menggunakan Aspergillus niger 2\% terhadap kualitas fisik dan kandungan nutrien. Materi dalam penelitian ini adalah limbah buah nanas kering berupa bagian mahkota, kulit nanas, mata nanas, hati nanas, dan Aspergillus niger. Metode yang digunakan dalam penelitian ini adalah metode percobaan dengan menggunakan Rancangan Acak Lengkap (RAL) dengan 3 perlakuan dan 4 kali ulangan. Perlakuan penelitian ini yaitu, $P_{0}=$ limbah buah nanas kering tanpa fermentasi, $P_{1}=$ limbah buah nanas kering + Aspergillus niger $2 \%$ difermentasi selama 4 hari, $P_{2}=$ limbah buah nanas kering + Aspergillus niger $2 \%$ difermentasi selama 6 hari. Hasil penelitian ini menunjukkan karakteristik fisik campuran limbah buah nanas dengan Aspergillus niger menghasilkan warna hijau kecokelatan sampai hijau kekuningan, memiliki aroma segar dan asam, tekstur tidak terlalu keras, dan ada tidaknya keberadaan jamur. Hasil analisis proksimat kandungan nutrien fermentasi limbah buah nanas menggunakan Aspergillus niger dengan lama waktu yang berbeda memberikan pengaruh yang berbeda sangat nyata $(P<0,01)$ terhadap perubahan kandungan nutrien $B K$, $B O$, dan $P K$, tetapi tidak berbeda nyata $(P>0,05)$ terhadap $S K$. Kesimpulan dari penelitian ini adalah fermentasi limbah buah nanas dengan lama waktu fermentasi 4 hari dengan menggunakan Aspergillus niger 2\% dapat mengubah kualitas fisik dan meningkatkan kandungan nutrien.
\end{abstract}

Kata Kunci : Limbah buah nanas, fermentasi, dan aspergillus niger

How to Cite :

Kusuma, A. P., Chuzaemi, S., \& Mashudi. (2019). Pengaruh Lama Waktu Fermentasi Limbah Buah Nanas (Ananas comosus L. Merr) Terhadap Kualitas Fisik dan Kandungan Nutrien Menggunakan Aspergillus niger. Jurnal Nutrisi Ternak Tropis 2 (1) 1-9
*Corresponding author :

Adi Prasetya Kusuma

Email : adiprasetyakusuma17@gmail.com

Fakultas Peternakan, Universitas Brawijaya Jalan Veteran, Ketawanggede, Kec. Lowokwaru, Kota Malang, Jawa Timur 65145 


\section{ABSTARCT}

The purpose of this research was to know how long the fermentation of waste pineapple fruit with Aspergillus niger 2\% on the physical quality and nutrient contents. The material in this research was the dried pineapple fruit waste in the crown section, the pineapple peels, pineapple eyes, axis, and Aspergillus niger. The method used in this study was an experiment with Completely Randomized Design. The experiment with 3 treatments and 4 replications. The 3 treatments were $P_{0}$ (pineapple waste without fermentation), $P_{1}$ (pineapple waste + Aspergillus niger 2\% during four days), $P_{2}$ (pineapple waste + Aspergillus niger $2 \%$ during six days). The result showed the pyhsical characteristics of mixed waste pineapple fruit with Aspergillus niger produces the color of green tanned until yellowish green, having the fresh smells and acid, the texture wasn't hard and not malleable, and almost no fungi in all treatments or the existence of fungi only slightly. The proximate analysis showed that waste fermentation lenght of pineapple fruit waste using Aspergillus niger $2 \%$ gave highly significant $(P<0.01)$ to changes in the nutrients DM, OM, CP, and did not gave significantly different $(P>0.05)$ on $C F$. It could be concluded that fermentation of waste pineapple fruit for 4 days and using Aspergillus niger $2 \%$ increased physical quality and nutrient contents value.

Keyword : Pineapple fruit waste, fermentation, aspergillus niger

\section{PENDAHULUAN}

Buah nanas (Ananas comosus L. Merr) merupakan salah satu jenis buah tropis yang terdapat di Indonesia dengan penyebaran merata. Buah nanas banyak dimanfaatkan oleh sebagian besar masyarakat untuk kebutuhan konsumsi. Selain dikonsumsi dalam kondisi segar, nanas juga banyak digunakan sebagai bahan baku industri perkebunan dengan berbagai hasil produk macam olahan nanas seperti selai, manisan, sirup, dodol, keripik, buah kaleng, dan lain-lain. Berdasarkan data dari Badan Pusat Statistika (2016) produksi buah nanas pada tahun 2016 adalah sebesar 1.396.153 ton. Pencapaian tersebut menghasilkan limbah dari buah nanas yang mencapai $27 \%$ dari total produksi buah nanas (Nurhayati dan Berliana, 2014).

Limbah buah nanas terdiri dari: kulit, mata, dan hati. Kulit nanas mengandung air $81,72 \%$, karbohidrat $17,53 \%$, protein $4,41 \%$, gula pereduksi $13,65 \%$, dan serat kasar 20,87\%. Sedangkan Nurhayati dan Berliana (2014) menjelaskan bahwa kulit nanas masih memiliki nilai gizi yang baik yaitu bahan kering (BK) 88,95\%, abu $3,82 \%$, serat kasar (SK) $27,09 \%$, protein kasar (PK) 8,78\%, dan lemak kasar (LK)
1,15\%. Limbah buah nanas yang tidak dimanfaatkan akan menimbulkan bau yang tidak sedap, terjadi kekurangan $\mathrm{O}_{2}$ karena selama proses perombakan oleh mikroorganisme memerlukan oksigen untuk mendukung pertumbuhannya serta terjadi pelepasan gas metan $\left(\mathrm{CH}_{4}\right)$ dan $\mathrm{CO}_{2}$ yang menaikkan emisi penyebab efek rumah kaca yang memicu global warming.

Potensi limbah buah nanas sampai saat ini sebagai sumber pakan ternak cukup tinggi, karena tingkat rendemen sekitar $15 \%$, dapat diartikan bahwa hasil dari limbah kulit nanas dan limbah perasan daging buah berkisar $85 \%$ dari produksi nanas. Terdapat sekiar 596 ribu ton per tahun limbah kulit nanas yang dapat digunakan sebagai bahan pakan ternak alternatif. Kulit nanas memiliki nutrien yang cukup tinggi yaitu bahan kering 14,22\%, protein kasar 3,50\%, serat kasar 19,69\%, lemak kasar 3,49\%, dan Neutral Deterget Fibre (NDF) $57,27 \%$ dan merupakan sumber energi dengan kandungan Gross Energy 4481 kkal/kg (Ginting, dkk. 2005). Kulit nanas masih memiliki nutrien yang cukup baik yaitu bahan kering $88,95 \%$, abu $3,82 \%$, serat kasar $27,09 \%$, protein kasar $8,78 \%$, dan lemak kasar $1,15 \%$. Kulit nanas berpotensi sebagai sumber pakan ternak 
(Nurhayati, 2013). Limbah nanas yang belum banyak dimanfaatkan dan hanya dibuang sehingga akan menimbulkan masalah lingkungan atau pencemaraan lingkungan maka pemanfaatan limbah buah nanas perlu diperhatikan untuk mengatasi hal tersebut. Salah satu alternatif pemanfaatan dari limbah buah nanas yaitu dapat dilakukan dengan fermentasi.

Fermentasi merupakan suatu proses terjadinya perubahan kimia pada suatu substrat organik melalui aktivitas enzim yang dihasilkan oleh mikroorganisme. Nutrien yang paling dibutuhkan oleh mikroba baik untuk tumbuh maupun untuk menghasilkan produk fermentasi adalah karbohidrat. Karbohidrat merupakan sumber karbon yang berfungsi sebagai penghasil energi bagi mikroba, sedangkan nutrien lain seperti protein dibutuhkan dalam jumlah lebih sedikit daripada karbohidrat (Azizah, dkk. 2012). Tujuan dari penelitian ini adalah untuk mengetahui lama waktu fermentasi limbah buah nanas menggunakan Aspergillus niger terhadap kualitas fisik dan kandungan nutrien.

\section{MATERI DAN METODE}

\section{Lokasi dan Waktu Penelitian}

Penelitian dilaksanakan pada tanggal

24 September-30 Oktober 2017 di Laboratorium Nutrisi dan Makanan Ternak Fakultas Peternakan Universitas Brawijaya.

\section{Materi Penelitian}

Bahan pembuatan fermentasi limbah buah nanas:

1. Limbah buah nanas (mahkota, daging, mata, dan kulit).

2. Aspergillus niger (kepadatan $\pm 3 \times 10^{7}$ yang didapat dari Pusat Studi Pangan dan Gizi Universitas Gadjah Mada Yogyakarta).

\section{Metode Penelitian}

Metode yang digunakan dalam penelitian ini adalah percobaan dengan menganalisis kualitas fisik dan kandungan nutrien menggunakan Rancangan Acak
Lengkap (RAL) dengan 3 perlakuan dan 4 kali ulangan. Perlakuan tersebut adalah sebagai berikut:

$\mathrm{P}_{0}=$ Limbah nanas kering tanpa perlakuan.

$\mathrm{P}_{1}=$ Limbah nanas kering + Aspergillus niger 2\% difermentasi selama 4 hari.

$\mathrm{P}_{2}=$ Limbah nanas kering + Aspergillus niger 2\% difermentasi selama 6 hari.

\section{Variabel Penelitian}

a) Penentuan kualitas fisik berupa warna, aroma, tekstur, dan keberadaan jamur dilakukan secara organoleptik menggunakan 20 panelis semi terlatih.

b) Penentuan kandungan nutrien berupa BK, BO, PK, dan SK dilakukan menggunakan analisis proksimat.

\section{HASIL DAN PEMBAHASAN}

\section{Warna}

Pengujian kualitas fisik warna dilakukan dengan pengamatan sampel dengan menggunakan penglihatan panelis. Umumnya warna fermentasi yang baik adalah hijau atau kecokelatan. Data pada Tabel 1 menunjukkan bahwa lama waktu fermentasi limbah buah nanas yang berbeda menggunakan Aspergillus niger menghasilkan warna hijau kecokelatan sampai hijau kekuningan.

Perubahan warna terjadi disebabkan oleh peningkatan suhu fermentasi anaerob berlangsung, perubahan warna yang terjadi pada tanaman yang mengalami proses fermentasi terjadi karena proses respirasi aerobik yang berlangsung selama persediaan oksigen masih ada hingga persediaan gula tanaman habis. Gula akan teroksidasi menjadi $\mathrm{CO}_{2}$ dan air sehingga terjadi panas yang mengakibatkan temperatur naik.

Apabila temperatur tidak terkendali maka pakan fermentasi akan berwarna cokelat tua hingga hitam. Hal ini menyebabkan turunnya nilai nutrien pada pakan. Abelhadi, Santini, and Galgiostro (2005) menyatakan bahwa fermentasi yang baik memiliki warna yang tidak jauh berbeda dengan warna bahan bakunya. 


\section{Aroma}

Pengujian karakteristik fisik aroma fermentasi limbah buah nanas menggunakan Aspergillus niger dengan lama waktu fermentasi yang berbeda didapatkan bahwa rata-rata perlakuan memiliki aroma segar dan sedikit asam. Hal ini berdasarkan seluruh data panelis yang ada. Pada perlakuan $\mathrm{P}_{2}$ dengan lama inkubasi 6 hari memiliki dominasi rata-rata aroma sedikit asam dibandingkan dengan perlakuan lainnya. Fermentasi yang baik memiliki aroma asam segar karena mengandung asam laktat, bukan aroma yang menyengat (Lamid, dkk. 2012).

Aroma asam fermentasi pakan disebabkan karena pada proses fermentasi terjadi penguraian nutrien khususnya karbohidrat menjadi asam organik. Kurnianingtyas dkk., (2012) aroma dihasilkan selama proses fermentasi disebabkan dalam proses pembuatan bakteri anaerob aktif bekerja menghasilkan asam organik. Terbentuknya asam pada waktu fermentasi mengakibatkan penuruan $\mathrm{pH}$, keadaan ini menghambat proses respirasi, proteolisis, dan mencegah aktifnya bakteri Clostridia. Fermentasi Clostridia akan menimbulkan bau busuk (Mc Donald, 2002). Pada perlakuan fermentasi limbah buah nanas menggunakan Aspergillus niger dengan lama fermentasi berbeda didapatkan hasil sedikit asam dan aroma khas fermentasi yang baik.

\section{Tekstur}

Berdasarkan hasil dari uji karakteristik fisik tekstur yang terdapat pada Tabel 1 menunjukkan bahwa lama fermentasi berbeda memiliki pengaruh yang sangat berbeda nyata $(\mathrm{P}<0,01)$ terhadap tekstur pakan fermentasi. Perlakuan terbaik pada $\mathrm{P}_{1}$ karena memiliki tekstur yang baik, yaitu tidak terlalu keras dan tidak terlalu lunak. Hal ini sesuai dengan Raldi dkk., (2015) menyatakan bahwa tekstur fermentasi yang baik adalah sesuai dengan tekstur bahan awal dan tidak terlalu lunak. Fermentasi berkualitas baik yaitu mempunyai tekstur segar yang masih seperti bahan baku awal.
Tekstur padat dan keras dihasilkan karena penurunan $\mathrm{pH}$ yang cepat pada proses fermentasi sehingga menekan pertumbuhan mikroba pembusuk. (Heinritz, 2011 dalam Kurnianingtyas dkk., 2012) menyatakan $\mathrm{pH}$ yang rendah akan menyebabkan mikroba pembusuk tidak dapat tumbuh sehingga tekstur yang dihasilkan padat dan tidak berlendir.

\section{Keberadaan Jamur}

Berdasarkan hasil uji karakteristik fisik keberadaan jamur yang terdapat pada Tabel 1 menunjukkan bahwa lama fermentasi berbeda memberikan pengaruh yang tidak berbeda nyata $(\mathrm{P}>0,05)$. Pengujian keberadaan jamur yang dilakukan oleh para panelis didapatkan hasil bahwa hampir semua perlakuan tidak terdapat adanya jamur atau hanya sedikit keberadaan jamur yang terdapat pada limbah buah nanas terfermentasi. Hal ini disebabkan dalam proses fermentasi terdapat bakteri anaerob saja yang masih aktif terutama bakteri pembentuk asam.

Bakteri anaerob tersebut berkembang dengan baik karena adanya penggunaan sumber karbon yang menstimulasi perkembangan bakteri asam laktat yang mengubah karbohidrat bahan menjadi asam laktat sehingga $\mathrm{pH}$ rendah. $\mathrm{pH}$ yang kurang dari 4 akan dapat menghambat tumbuhnya jamur dan terbentuknya lendir. Kondisi anaerob didalam silo tercapai dengan baik sehingga jamur sukar untuk tumbuh. Tidak adanya jamur disebabkan karena tidak adanya oksigen dalam silo, sehingga hanya bakteri anaerob yang masih aktif untuk proses ensilase (Raldi, dkk. 2015).

\section{Kandungan Bahan Kering (BK)}

Data pada Tabel 2 menunjukkan bahwa kandungan nutrisi limbah buah nanas yang difermentasi menggunakaan Aspergillus niger dengan lama inkubasi yang berbeda mengalami perubahan dibandingkan dengan limbah buah nanas yang tidak difermentasi $\left(\mathrm{P}_{0}\right)$. Kurniawan dkk., (2016) menjelaskan bahwa fermentasi menyebabkan penurunan kandungan BO yang diikuti dengan penurunan kandungan BK yang dimanfaatkan mikroba sebagai 
sumber energi akibat terjadi penguraian oleh aktivitas mikroba yang menghasilkan enzim sehingga dapat mendegradasi $\mathrm{BO}$ dan kandungan abu menjadi naik.

Lama waktu inkubasi yang berbeda mempengaruhi kandungan bahan kering. Persentase kandungan bahan kering pakan disajikan pada Tabel 2 hasil analisis proksimat kandungan nutrien limbah buah nanas dengan lama waktu fermentasi yang berbeda menggunakan Aspergillus niger memberikan pengaruh yang berbeda sangat nyata $(\mathrm{P}<0,01)$ terhadap perubahan kandungan nutrisi bahan kering. Penurunan kandungan bahan kering seiring dengan semakin lama waktu inkubasi pada fermentasi limbah buah nanas. Kandungan
BK tertinggi terdapat pada perlakuan $\mathrm{P}_{0}$ dengan BK 40,15\%, kemudian diikuti dengan $\mathrm{P}_{1} 32,77 \%$ dan $\mathrm{P}_{2} 31,73 \%$.

Perlakuan terbaik pada $\mathrm{P}_{1}$ dan $\mathrm{P}_{2}$ karena memiliki kandungan $\mathrm{BK}$ yang paling ideal dibandingkan perlakuan lainnya yaitu BK $32,77 \%$ dan 31,73\%. Hal ini sesuai dengan pendapat Kaiser, et al. (2004) menyatakan bahwa kandungan BK yang mengindikasikan fermentasi berkualitas baik adalah yang memiliki kandungan BK antara 30-40\%. Pakan fermentasi yang kandungan bahan kering terlalu tinggi beresiko terbakar dan yang memiliki kadar bahan kering terlalu rendah beresiko ditumbuhi jamur.

\section{Kandungan Nutrien Pakan Perlakuan}

Tabel 1. Rataan kualitas fisik fermentasi limbah buah nanas dengan Aspergillus niger.

\begin{tabular}{lccc}
\hline Karakteristik & \multicolumn{3}{c}{ Perlakuan } \\
\cline { 2 - 4 } & $\mathrm{P}_{0}$ & $\mathrm{P}_{1}$ & $\mathrm{P}_{2}$ \\
\hline Warna & $3^{\mathrm{b}} \pm 1,13$ & $3^{\mathrm{b}} \pm 1,06$ & $2^{\mathrm{a}} \pm 0,89$ \\
\hline Aroma & $3^{\mathrm{a}} \pm 1,05$ & $3^{\mathrm{a}} \pm 1,00$ & $4^{\mathrm{b}} \pm 1,01$ \\
\hline Tekstur & $2^{\mathrm{a}} \pm 0,82$ & $3^{\mathrm{b}} \pm 0,92$ & $4^{\mathrm{c}} \pm 1,29$ \\
\hline Keberadaan Jamur & $2 \pm 1,09$ & $2 \pm 0,85$ & $2 \pm 1,05$ \\
\hline
\end{tabular}

Keterangan :

1). Superskrip berbeda ${ }^{(\mathrm{a}-\mathrm{b})}$ pada kolom yang sama (warna) memberikan pengaruh yang sangat berbeda nyata $(\mathrm{P}<0,01)$.

2). Superskrip berbeda ${ }^{(a-b)}$ pada kolom yang sama (aroma) memberikan pengaruh yang sangat berbeda nyata $(\mathrm{P}<0,01)$.

3). Superskrip berbeda ${ }^{(\mathrm{a}-\mathrm{b})}$ pada kolom yang sama (tekstur) memberikan pengaruh yang sangat berbeda nyata $(\mathrm{P}<0,01)$.

Tabel 2. Rataan kandungan nutrien pakan limbah buah nanas yang difermentasi pada masingmasing perlakuan.

\begin{tabular}{ccccc}
\hline Perlakuan & BK $(\%)$ & BO $(\%)$ & PK $(\%)$ & SK $(\%)$ \\
\hline $\mathrm{P}_{0}$ & $40,15^{\mathrm{b}} \pm 0,90$ & $93,56^{\mathrm{b}} \pm 0,18$ & $6,75^{\mathrm{a}} \pm 0,51$ & $13,23 \pm 2,21$ \\
$\mathrm{P}_{1}$ & $32,77^{\mathrm{a}} \pm 0,86$ & $92,79^{\mathrm{a}} \pm 0,28$ & $9,55^{\mathrm{b}} \pm 0,69$ & $14,69 \pm 1,18$ \\
$\mathrm{P}_{2}$ & $31,73^{\mathrm{a}} \pm 1,53$ & $92,80^{\mathrm{a}} \pm 0,26$ & $9,02^{\mathrm{b}} \pm 0,41$ & $16,85 \pm 1,52$ \\
\hline
\end{tabular}

Keterangan : ${ }^{\mathrm{a}-\mathrm{b})}$ Superksrip yang berbeda pada kolom yang sama memberikan perbedaan yang sangat nyata $(\mathrm{P}<0,01)$

*Berdasarkan 100\% BK

\section{Kandungan Bahan Organik (BO)}

Hasil analisis proksimat kandungan nutrien limbah buah nanas dengan lama waktu fermentasi yang berbeda menggunakan Aspergillus niger memberikan pengaruh yang berbeda sangat nyata $(\mathrm{P}<0,01)$ terhadap perubahan kandungan nutrisi bahan organik. Data pada Tabel 2 menunjukkan bahwa kandungan BO tertinggi pada $\mathrm{P}_{0} 93,56 \%$ dan terendah pada 
$\mathrm{P}_{1} 92,79 \%$. Perubahan kimiawi yang terjadi selama proses fermentasi akibat aktivitas mikroba yang mendegradasi salah satu komponen dari BO yaitu SK sehingga mikroba memanfaatkan sebagai sumber karbon untuk perkembangan, pertumbuhan, dan aktivitasnya.

Hal ini sesuai dengan Christi, Ana, dan Iman (2016) bahwa dalam proses fermentasi menyebabkan penurunan jumlah bahan kering yang diakibatkan karena adanya kebutuhan energi oleh mikroba yang memecah substrat karbohidrat yang menghasilkan energi dalam bentuk panas, $\mathrm{CO}_{2}$, dan $\mathrm{H}_{2} \mathrm{O}$.

\section{Kandungan Protein Kasar (PK)}

Hasil analisis proksimat kandungan nutrien limbah buah nanas dengan lama waktu fermentasi yang berbeda menggunakan Aspergillus niger memberikan pengaruh yang berbeda sangat nyata $(\mathrm{P}<0,01)$ terhadap kandungan nutrisi protein kasar. Peningkatan kandungan PK pada masing-masing perlakuan limbah buah nanas yang telah difermentasi menggunakan Aspergillus niger meningkat, pada awalnya tanpa perlakuan $\left(\mathrm{P}_{0}\right)$ sebesar $6,75 \%$ mengalami peningkatan pada perlakuan hari ke-4 $\left(\mathrm{P}_{1}\right)$ sebesar $9,55 \%$ kemudian mengalami penurunan seiring bertambahnya waktu fermentasi yaitu pada hari ke-6 $\left(\mathrm{P}_{2}\right)$ sebesar $9,02 \%$. Peningkatan protein diduga karena adanya penambahan protein yang disumbangkan oleh sel mikroba akibat pertumbuhannya yang menghasilkan produk protein sel tunggal (PST) atau biomassa sel yang mengandung sekitar $40-65 \%$ protein (Krisnan et al., 2005).

Penurunan PK pada proses fermentasi ini disebabkan karena pada lama waktu fermentasi 6 hari pertumbuhan Aspergillus niger sudah pada fase death phase (fase kematian) sehingga mengalami lisis dan protein yang terkandung didalam selnya terurai menjadi non protein misalnya berupa amonia, hal ini menyebabkan kadar PK dari produk fermentasi menjadi turun.

Idiawati dkk., (2014) mengatakan bahwa aktivitas enzim selulase akan semakin meningkat seiring dengan bertambahnya waktu fermentasi. Akan tetapi, terjadi pula penurunan seiring dengan bertambahnya waktu fermentasi karena konsentrasi substrat mulai menurun, sehingga menyebabkan laju pertumbuhan menurun. Menurut Riswandi (2014), menyatakan bahwa perubahan hasil fermentasi pakan terjadi akibat aktivitas mikroba dan terjadi interaksi antara hasil degradasi oleh enzim atau mikroba dengan komponen yang ada dalam bahan pakan.

Hal ini juga sesuai dengan Wina (2005) bahwa terjadinya penurunan protein disebabkan oleh adanya degradasi protein selama proses penyimpanan karena aktivitas mikroba dan larut dalam air. Mikroba yang menyebabkan penurunan protein adalah jenis proteolitik. Protein akan dirombak oleh mikroba proteolitik menjadi asam amino dan $\mathrm{NH}_{3}$ selama proses fermentasi sehingga akan mengakibatkan penurunan protein.

Perlakuan terbaik didapat pada perlakuan $\mathrm{P}_{1}$ karena terjadi peningkatan protein kasar yang cukup tinggi mencapai $9,55 \%$. Peningkatan ini diduga terjadi karena bakteri mampu menggunakan bagian dari substrat untuk pertumbuhan dan pembentukan protein mikroba selama proses fermentasi dengan sempurna. Selain itu juga waktu terbaik fermentasi menggunakan Aspergillus niger yaitu 4 hari yang juga merupakan lama waktu inkubasi dari perlakuan $\mathrm{P}_{1}$.

Peningkatan PK pada perlakuan yang terjadi selama proses fermentasi berlangsung dipengaruhi oleh adanya protein yang disumbangkan oleh tubuh mikroba akibat pertumbuhan. Menurut Anggorodi (2005) bahwa kandungan protein kasar setelah fermentasi sering mengalami peningkatan yang disebabkan karena mikroba mempunyai pertumbuhan dan perkembangbiakan yang baik, dapat mengubah lebih banyak komponen penyusun yang berasal dari tubuh mikroba itu sendiri yang akan meningkatkan kandungan protein kasar dari substrat. Meningkatnya kandungan protein kasar disebabkan karena bakteri berkembangbiak pada ransum ruminansia. Protein kasar yang 
terkandung dalam bakteri yaitu $60 \%$ (Moran, 2005), oleh sebab itu bakteri yang berkembang biak dalam ransum ruminansia dapat meningkatkan protein kasar dalam ransum tersebut (Samadi, Sitti, dan Sabda 2015).

\section{Kandungan Serat Kasar (SK)}

Hasil analisis proksimat kandungan nutrien limbah buah nanas dengan lama waktu fermentasi yang berbeda menggunakan Aspergillus niger memberikan pengaruh yang tidak berbeda nyata $(\mathrm{P}>0,05)$ terhadap perubahan kandungan nutrisi serat kasar. Data pada Tabel 2 diketahui bahwa kandungan SK semakin meningkat seiring dengan bertambahnya waktu fermentasi, dapat dilihat dari kandungan SK limbah buah nanas tanpa perlakuan $\mathrm{P}_{0}$ sebesar $13,23 \%$, $\mathrm{P}_{1} 14,69 \%$ kemudian meningkat hingga $16,85 \%$ pada $\mathrm{P}_{2}$.

Peningkatan SK pada proses fermentasi disebabkan karena terjadi akumulasi SK seiring dengan perkembangbiakan Aspergillus niger yang diikuti dengan meningkatnya miselium. Hal ini sesuai dengan penelitian Mirwandhono dkk., (2006) yang menyatakan bahwa kandungan serat kasar pakan hasil fermentasi dipengaruhi oleh pertumbuhan jamur (miselium) pada kapang, sehingga semakin lama waktu fermentasi maka akan semakin menghasilkan pertumbuhan miselium yang lebat dan terjadi peningkatan kandungan serat kasar.

Hal ini didukung oleh Ria, Nora, dan Lia (2012) menyatakan bahwa semakin lama waktu inkubasi pada proses fermentasi maka kandungan serat kasar semakin tinggi pula. Hal ini disebabkan oleh pertumbuhan kapang yang ikut menyumbang serat kasar yang berasal dari miselium sehingga semakin banyak massa sel makin tinggi kadar seratnya.

\section{KESIMPULAN}

1. Fermentasi limbah buah nanas menggunakan Aspergillus niger 2\% dengan lama waktu fermentasi 4 hari dapat merubah karakteristik fisik limbah buah nanas baik dari warna, aroma, dan tekstur.

2. Fermentasi limbah buah nanas menggunakan Aspergillus niger 2\% dengan lama waktu inkubasi 4 hari merupakan waktu optimal untuk menghasilkan nilai kandungan nutrien terbaik dengan kandungan sebesar BO $92,79 \%$, PK 9,55\%, SK 14,69\%.

\section{SARAN}

Perlu dilakukan penelitian lebih lanjut mengenai fermentasi limbah buah nanas menggunakan Aspergillus niger 2\% dengan lama waktu fermentasi $(0,4$, dan 6 hari) terhadap kecernaan secara in vivo.

\section{DAFTAR PUSTAKA}

Abdelhadi, L., Santini, F., \& Gagliostro, G. (2005). Corn silage or high moisture corn supplements for beef heifers grazing temperate pastures: Effects on performance, ruminal fermentation and in situ pasture digestion. Animal Feed Science and Technology, 118(1-2), 63-78.

Anggorodi, R. (2005). Ilmu Makanan Ternak Umum. Yogyakarta: Gadjah Mada University Press.

Azizah, N., Al-Barrii, A. N., \& Mulyani, S. (2012). Pengaruh lama fermentasi terhadap kadar alkohol, ph, dan produksi gas pada proses fermentasio bioetanol dari whey dengan substitusi kulit nanas. Jurnal Aplikasi Teknologi Pangan, 1(3), 72-78. 
Badan Pusat Statistik. (2016). Produksi Buah-Buahan dan Sayuran Tahunan di Indonesia. Jakarta: Badan Pusat Statistik.

Christi, Febrianto, R., Rochana, A., \& Hernaman, I. (2016). Pengaruh Konsentrat Terfermentast erhadap Kandungan Energi Bruto, Serat Kasar, dan Protein Kasar. Sumedang: Prosiding Seminar Nasional Peternakan Berkelanjutan.

Fransistika, R., Idiawati, N., \& Dest, L. (2013). Pengaruh waktu fermentasi campuran trichoderma reesei dan aspergillus niger terhadap kandungan protein dan serat kasar ampas sagu. Jurnal Kimia Khatulistiwa, 1(1), 35-39.

Ginting, S. P., Krisnan, R., \& Simanihuruk, K. (2005). Substitusi Hijauan Dengan Limbah Nanas Dalam Pakan Komplit Pada Kambing. Seminar Nasional Teknologi Peternakan dan Veteriner.

Heinritz, S. N., Martens, S. D., Avila, P., \& Hoedtke, S. (2012). The effect of inoculant and sucrose addition on the silage quality of tropical forage legumes with varying ensilability. Animal Feed Science and Technology, 174(3-4), 201-210. https://doi.org/10.1016/j.anifeedsci.2012.03.017

Idiawati, N., Harfinda, E. M., \& Arianie, L. (2014). Produksi enzim selulase oleh aspergillus niger pada ampas sagu. Jurnal Natur Indonesia, 16(1), 1-9.

Kaiser, A. G., Piltz, J., Burns, H. M., \& Griffiths, N. W. (2004). Successful Silage. Dairy Australia and New South Wales Department of Primary Industries.

Kojo, R. M., Rustandi, Y. R. L., Tulung, \& Malalantang, S. S. (2015). Pengaruh penambahan dedak padi dan tepung jagung terhadap kualitas fisik silase rumput gajah (pennisetum purpureum cv. hawaii). Jurnal Zootek, 35(1), 21-29.
Krisnan, R. (2005). The effect of application of tea waste (Camellia sinensis) fermented with Aspergillus niger on broiler. Jurnal Ilmu Ternak Dan Veteriner, $10(1), \quad 1-5$. https://doi.org/10.14334/JITV.V10I1.470

Kurnianingtyas, I., Pandasari, P. R., Astuti, I., Widyawat, S. D., \& Suprayogi, W. P. S. (2012). Pengaruh macam akselerator terhadap kualitas fisik, kimiawi, dan biologi silase rumput kolonjono. Tropical Animal Husbandy, 1(1), 7-14.

Kurniawan, H. (2016). Kualitas nutrisi ampas kelapa (cocos nuficena) fermentasi menggunakan aspergillus niger. Buletin Peternakan, 40(1), 26-33. https://doi.org/10.21059/buletinpeternak.v40i1.9822

Lamid, M., Ismudiono, Koestono, S., Chusniati, \& Vina. (2012). Karakteristik silase pucuk tebu (saccharum officinarum, linn) dengan penambahan lactobacillus plantarum. Jurnal Agroveteriner, 1(1), 1-10.

McDonald, I. (1981). A revised model for the estimation of protein degradability in the rumen. The Journal of Agricultural Science, 96(1), 251-252. https://doi.org/10.1017/S0021859600032081

Mirwandhono, E., Situmorang, D., \& Bachari, I. (2006). Uji nilai nutrisi kulit ubi kayu yang difermentasi dengan aspergillus niger. Jurnal Agribisnis Peternakan, 2(3), 91-95.

Moran, J. (2005). Tropical Dairy Farming: Feeding Management for Small Holder Dairy Farmers in the Humid Tropics. Collingwood. Australia: Landlinks Press.

Nurhayati. (2013). Penampilan ayam pedaging yang mengkonsumsi pakan mengandung kulit nanas disuplementasi dengan yoghurt. Agripet, 13(2), 15-20. 
Nurhayati, N., \& Berliana. (2014). Perubahan kandungan protein dan serat kasar kulit nanas yang difermentasi dengan plain yoghurt. Jurnal Ilmiah Ilmu-Ilmu Peternakan, 15(1).

Riswandi. (2014). Kualitas silase eceng gondok (eichhornia crassipes) dengan penambahan dedak halus dan ubi kayu. Jurnal Peternakan Sriwijaya, 3(1), 1-6.
Samadi, Wajizah, S., \& Sabda. (2015). Peningkatan kualitas ampas tebu sebagai pakan ternak melalui fermentasi dengan penambahan level tepung sagu yang berbeda. Agripet, 15(2), 104-111.

Wina, E. (2005). Teknologi pemanfaatan mikroorganisme dalam pakan untuk meningkatkan produktivitas ternak ruminansia di indonesia. Wartazoa, 15(4), 173-186. 